XXX. European Union

\title{
A. Legislation
}

\section{Product Liability}

1 As mentioned in last year's report, ${ }^{1}$ the EU Commission set up an Expert Group on liability and new technologies, ${ }^{2}$ of which one subgroup, ${ }^{3}$ the 'Product Liability Directive Formation', is commissioned to assess the Product Liability Directive (PLD) ${ }^{4}$ and its potential needs for reform or at least clarification. The work of this subgroup has not been concluded so far, however, so it is yet premature to predict the potential outcome, let alone to what extent it will ever be implemented. At the time of drafting, it seemed that the PLD formation would not propose any reform of the blackletter text of the PLD, but rather opt for a mere guidance document that is intended to clarify some matters currently under debate. If that should be the final result, this would be deplorable in light of the manifold weaknesses of the PLD text as it stands in light of modern-day needs. ${ }^{5}$ Products and production have changed dramatically over the past 35 years, so it seems unconvincing that a legislative text drafted in the mid-1970s is still appropriate for handling the needs of the Internet of Things (IoT) and comparable new technologies.

1 BA Koch/T Thiede, European Union, in: E Karner/BC Steininger (eds), European Tort Law (ETL) 2018 (2019) 698, no 11.

2 Expert Group on liability and new technologies, <http://ec.europa.eu/transparency/regexpert/index.cfm? do= groupDetail.groupDetail\& groupID=3592>.

3 See infra no $2 \mathrm{ff}$ on the second subgroup.

4 Council Directive 85/374/EEC of 25 July 1985 on the approximation of the laws, regulations and administrative provisions of the Member States concerning liability for defective products [1985] Official Journal (OJ) L 210/29, as amended by Directive 1999/34/EC of the European Parliament and of the Council of 10 May 1999 [1999] OJ L 141/20.

5 See, eg, P Machnikowski (ed), European Product Liability. An Analysis of the State of the Art in the Era of New Technologies (2016), in particular the editor's conclusions at $669 \mathrm{ff}$. 


\section{Liability for Emerging Digital Technologies}

The second subgroup of the above-mentioned EU Expert Group on liability and 2 new technologies ${ }^{6}$ was tasked to assess whether and to what extent existing liability regimes are still suitable to cope with the risks brought about by new technologies such as Artificial Intelligence, advanced robotics, the IoT and cybersecurity flaws. This second subgroup published its final report on 'Liability for Artificial Intelligence and Other Emerging Digital Technologies' at the end of 2019. ${ }^{7}$

The expert group took note of the peculiar challenges posed by emerging 3 digital technologies, but stated from the outset that these cannot be met with a one-size-fits-all solution. Still, '[c]omparable risks should be addressed by similar liability regimes', ${ }^{8}$ but in light of the existing spectrum of liability regimes. Therefore, for example, it may be suitable to foresee strict liability for certain technologies if these show features comparable to other risks already linked to strict liability: 'The mere fact that technology is new is not justification enough for introducing strict liability. Nevertheless, emerging digital technologies that may typically cause significant harm comparable to the risks already subject to strict liability should also be subject to strict liability."

The report further notices the 'key role' of producers' strict liability and $\mathbf{4}$ points to peculiar features of $\mathrm{AI}$ and other digital technologies which the current PLD regime does not address adequately, even if it were interpreted to apply to intangible products as well. Regular updates are difficult to align with the PLD's strict focus on the moment a product was put into circulation, as is its development risk defence. ${ }^{10}$

Other aspects the report tackles include the burden of proving causation ${ }^{11}$ and $\mathbf{5}$ fault ${ }^{12}$, as well as the relevance of logging the operation of digital technology. ${ }^{13}$

6 Above fn 2. BA Koch is a member of this subgroup.

7 <https://ec.europa.eu/transparency/regexpert/index.cfm?do=groupDetail.groupMeetingDo c\&docid=36608>. BA Koch co-drafted this final report together with PMachnikowski and $C$ Wendehorst.

8 Key Finding 5, final report (fn 7) 36.

9 Final report (fn 7) 40.

10 Final report (fn 7) $42 \mathrm{ff}$.

11 Final report (fn 7) $49 \mathrm{ff}$.

12 Final report (fn 7) $52 \mathrm{ff}$.

13 Final report (fn 7) $47 \mathrm{f}$. 
The expert group also underlines that 'it is not necessary to give autonomous systems a legal personality' in order to properly attribute the ensuing risks. ${ }^{14}$

It remains to be seen to what extent this report will trigger follow-up action at the Commission level.

\section{B. Cases}

\section{Court of Justice of the European Union (CJEU) 31 January 2019 - C-149/18, Agostinho da Silva Martins v Dekra Claims Services Portugal SA, ECLI:EU:C:2019:84}

\section{a) Brief Summary of the Facts}

7 On 20 August 2015, the claimant's vehicle, registered and insured in Portugal, collided with another car on Spanish territory. The latter car, whose driver was solely responsible for the crash, was registered and insured in Spain, the defendant is the Spanish insurer's representative. Due to the accident, the claimant's car could no longer be driven and therefore had to be towed back to Portugal, where it was repaired. The Spanish insurer reimbursed the cost of repair.

8 In an action filed in Portugal on 11 November 2016, the claimant seeks compensation for indirect damage allegedly resulting from the accident, arguing that the question should be resolved according to Portuguese law, which foresees a three-year limitation period for tort claims. The defendant contends that Spanish law should govern instead, according to which, the claim would already be time-barred as one year had lapsed since the accident.

9 The referring Portuguese appellate court inter alia wants to know whether the (longer) Portuguese limitation period could be interpreted as an overriding mandatory provision within the meaning of art 16 of the Rome II Regulation. ${ }^{15}$ Furthermore, it asks the CJEU whether the Portuguese rule could be seen as a provision 'more favourable to injured parties' within the meaning of art 28 of the Motor Insurance Directive (MID) ${ }^{16}$.

14 Final report (fn 7) $37 \mathrm{ff}$.

15 Regulation (EC) No 864/2007 of the European Parliament and of the Council of 11 July 2007 on the law applicable to non-contractual obligations (Rome II) [2007] OJ L 199/40.

16 Directive 2009/103/EC of the European Parliament and the Council of 16 September 2009 relating to insurance against civil liability in respect of the use of motor vehicles, and the enforcement of the obligation to ensure against such liability [2009] OJ L 263/11. On this Directive, 


\section{b) Judgment of the Court}

While it is clear from art 4 para 1 Rome II that a claim for compensation arising out 10 of the accident at stake should be governed by the laws of Spain since this is where the damage occurred, and that this extends to the rules of prescription as expressly foreseen by art 15 lit h Rome II, the Court considered whether the Portuguese limitation period could apply via art 16 Rome II. Since the latter rule fails to specify the term 'overriding mandatory provision', the Court deemed it necessary to look at the corresponding rule of art 9 para 1 of the Rome I Regulation ${ }^{17}$ instead, if only for reasons of consistency. The latter calls for 'provisions the respect for which is regarded as crucial by a country for safeguarding its public interests, such as its political, social or economic organisation, to such an extent that they are applicable to any situation falling within their scope, irrespective of the law otherwise applicable to the contract under this Regulation'.

As an exception to the main rule, the notion of 'overriding mandatory provi- $\mathbf{1 1}$ sion' must be interpreted strictly. The Court agrees with the Commission that triggering art 16 Rome II 'would require the identification of particularly important reasons, such as a manifest infringement of the right to an effective remedy and to effective judicial protection arising from the application of the law designated as applicable' (para 34). The Court was not entirely convinced that the Portuguese limitation period would meet that stringent test and therefore opined that it was not an overriding mandatory provision. However, it left a backdoor open for the Portuguese referring court, allowing the latter to still conclude that 'on the basis of a detailed analysis of the wording, general scheme, objectives and the context in which that provision was adopted' the prescription rule was still of such tremendous importance in the Portuguese legal order that it justifies a departure from the otherwise applicable law (para 35).

The Court further concluded that art 28 MID was not a conflict-of-law rule 12 within the meaning of art 27 Rome II, as 'there is nothing in the wording or the objectives of Directive 2009/103 to suggest that it is intended to lay down conflict-of-law rules'. ${ }^{18}$ Article 28 MID merely permits Member States to adopt rules

see D Hinghofer-Szalkay/BA Koch, European Union, in: H Koziol/BC Steininger (eds), European Tort Law (ETL) 2008 (2009) 647, no $1 \mathrm{ff}$.

17 Regulation (EC) No 593/2008 of the European Parliament and of the Council of 17 June 2008 on the law applicable to contractual obligations (Rome I) [2008] OJ L 177/6.

18 See already CJEU 21.1.2016, C-359/14 and C-475/14, ERGO Insurance and Gjensidige Baltic, ECLI:EU:C:2016:40, para 40. On this case, see BA Koch/T Thiede, European Union, in: E Karner/ BC Steininger (eds), ETL 2016 (2017) 646, no $11 \mathrm{ff}$ (no 13). 
more favourable for victims of traffic accidents than those foreseen by the MID and therefore only concerns the transposition of the Directive in that Member State and not whether the rules of any other country are to be applied (or barred by these domestic rules).

\section{c) Commentary}

13 The Court's ruling does not come as a major surprise - the message of art 15 lit $h$ Rome II is particularly clear: the law applicable according to this Regulation inter alia includes the 'rules of prescription and limitation' of that jurisdiction. However, the Court apparently felt uneasy with this outcome as it allows the referring court to still trigger art 16 Rome II, even though the threshold seems to be rather high.

14 The real problem evidenced once more by this ruling is the extreme diversity of prescription rules throughout Europe, ${ }^{19}$ which cannot be resolved simply by allowing Member States to randomly ignore extremely short limitation periods of another country. Traffic accidents with a high ratio of cross-border cases in particular are the most obvious example of how troublesome it is to preserve the current complexity. However, harmonising limitation periods just for traffic accidents alone ${ }^{20}$ may be an imperfect solution, as other tort cases would still be treated differently, and for no apparent justification.

\section{CJEU 14 March 2019 - C-724/17, Vantaan kaupunki v Skanska Industrial Solutions Oy and Others, ECLI:EU:C:2019:204}

\section{a) Brief Summary of the Facts}

15 The starting point of the Skanska case is a cartel on the Finnish asphalt market from 1994 to 2002. The defendants in the main proceedings acquired the companies participating in the cartel during this period, continued the business ac-

19 See, eg, B Askeland/I Gilead (eds), Prescription in Tort Law (2020).

20 See, eg, the initiative by the European Parliament and its Resolution of 4 July 2017 with recommendations to the Commission on limitation periods for traffic accidents (2015/2087 (INL)), P8_TA(2017)0281. 
tivities of the cartelists, and were fined under Finnish law for the infringements committed by the cartel members.

The Finnish City of Vantaa sued the defendants for excessive asphalting 16 costs, arguing that prices would have been lower without the cartel. The defendants argued that they were the buyers of the actual cartel members and could not be held responsible for the latter's conduct in tort since these had been independent companies at the time, and that Vantaa should have pursued its claims against these companies during the latter's liquidation proceedings.

The Finnish court of first instance, however, attributed the conduct of the $\mathbf{1 7}$ cartel members to the defendant purchasers as otherwise it would be impossible for cartel victims to obtain compensation for damage caused by the cartel after restructuring and liquidation of the cartelists. According to that court, it was obvious that the attribution of their conduct should follow the same principles in administrative law and in tort law. Since the defendants had been fined in administrative proceedings, they should also be liable for damage caused by the companies they had bought. In contrast, the appellate court dismissed the action.

In response to the plaintiff's appeal in cassation, the Finnish Supreme Court $\mathbf{1 8}$ initially held that, in principle, only the legal entity that had directly caused the damage was liable for damages. Nevertheless, the Finnish Supreme Court asked the CJEU whether and how the liable persons in competition law should be determined under European or under national law.

\section{b) Judgment of the Court}

The CJEU held that the capacity to be sued is not to be established under na- 19 tional law, but results from the direct application of European law (para 28): It follows from the very wording of art 101 Treaty on the Functioning of the European Union (TFEU) ${ }^{21}$ that an 'undertaking' is liable for damage caused by its activities (paras 29, 30). Any restructuring and subsequent liquidation, as in the present proceedings, does not exempt from liability, as the new undertaking is economically identical to the one that had ceased to exist (para 38).

21 Art 101 para 1 TFEU reads in relevant part: 'The following shall be prohibited as incompatible with the internal market: all agreements between undertakings, decisions by associations of undertakings and concerted practices which may affect trade between Member States and which have as their object or effect the prevention, restriction or distortion of competition within the internal market ...'? 
20 According to the Court it is, generally, not reasonable to differentiate between a single undertaking and a group of several legal persons, provided that the latter form an economic unit. The concept of 'undertaking', as an autonomous concept of European law, is to be interpreted in the same way in the law on fines for anti-competitive conduct and cartel damages (para 47).

\section{c) Commentary}

21 The content of the CJEU's decision is not surprising in view of the underlying facts. It was not to be expected that the Court would stand idly by when cartelists attempt to avoid their liability for damages by restructuring their group.

22 Since some Member States' legislators did not feel obliged to close the gap in the protection of victims of anti-competitive conduct when transposing the Cartel Damages Directive ${ }^{22}$, the Court's direct application of art 101 TFEU was foreseeable. Since the underlying problem of avoiding liability through restructuring also exists in the European law on fines for anti-competitive conduct, it was quite likely that the CJEU would now also apply these principles to claims for damages caused by cartels.

23 Overall, the decision will result in a significant increase in the number of liable legal entities in cartel damage claims. An 'undertaking' in the aforementioned European meaning is already created when individual companies are combined into an 'economic unit', for instance when economic, organisational or legal ties exist. Uniform external market conduct is used to assess these ties. Hence, subsidiaries will now be liable for their parent companies and vice versa.

24 Moreover, the CJEU's ruling will impact on due diligence in mergers and acquisitions. Since future purchasers will also have to pay for the cartel damage caused (even where there is an asset deal), due diligence will have to examine risks of purchaser's liability for any cartel damage claims against the seller of the respective assets.

22 Directive 2014/104/EU of the European Parliament and of the Council of 26 November 2014 on certain rules governing actions for damages under national law for infringements of the competition law provisions of the Member States and of the European Union [2014] OJ L 349/1. 


\section{CJEU 28 March 2019 - C-637/17, Cogeco Communications Inc v Sport TV Portugal SA and Others, ECLI:EU:C:2019:263}

\section{a) Brief Summary of the Facts}

The Portuguese national rules on limitation periods applicable in this case pro- $\mathbf{2 5}$ vided that the right to compensation was time-barred after a period of three years from the time when the injured party became aware of the right to compensation. That period began to run even if the injured party did not know the identity of the person liable and the full extent of the damage. Moreover, the period was not suspended or interrupted by proceedings before the national competition authority.

The original dispute itself concerned the abuse of a dominant market posi- 26 tion. In July 2009, Cogeco filed a formal complaint with the Portuguese competition authority against Sport TV Portugal for abuse of market power. According to the authority's decision issued in 2013, Sport TV Portugal had violated both art 102 TFEU as well as Portuguese competition law by abusing its dominant market position. In 2014, however, the Competition Court seised by Sport TV Portugal ruled that there was no infringement of art 102 TFEU. Shortly before the Appellate Competition Court upheld the fine, Cogeco brought an action for damages against Sport TV Portugal for cartel damages, in which Sport TV Portugal raised the prescription defence.

The Portuguese civil courts asked the CJEU to clarify whether the Cartel 27 Damages Directive, and in particular its provisions on limitation periods, were applicable to the case at hand, and whether and to what extent general principles of European law would provide guidelines for the applicability and interpretation of the national Portuguese rules on limitation periods in cartel damage claims.

\section{b) Judgment of the Court}

Since the action for damages was brought both before the expiry of the time- 28 limit for transposition and before the actual transposition of the Cartel Damages Directive into Portuguese law, and since the Portuguese rules then transposed did not provide for retroactive effect, the CJEU considered that neither the Directives' nor the Portuguese 'new' rules on limitation apply to the case (paras 2433).

Thus, the Court examined the national statute of limitations on the basis of 29 the principles of equivalence and effectiveness (para 42): as the relevant case 
law on art 101 TFEU applies accordingly to violations of art $102 \mathrm{TFEU}^{23}$ (para 28), national rules should not restrict the effectiveness of art 102 TFEU (para 44).

Against this background, and in view of the practical complexity of an action for damages (para 46), the short limitation period (para 48), the start of the period (para 49) and the lack of suspension due to an official investigation (para 50), the Court assumed that the limitation period in Portuguese law was incompatible with art 102 TFEU.

31 The Court neither commented on any preliminary applicability of the Cartel Damages Directive nor on the fact that Portuguese competition courts had held that this was not even a case under art 102 TFEU.

\section{c) Commentary}

32 The ruling is particularly relevant for those European legal systems which (prior to the transposition of the Cartel Damages Directive) provided for a rather restrictive statute of limitations.

Comments on the preliminary effects of said Directive would have been welcome. However, an unbiased reading suggests in fact that the CJEU was considerably 'guided' by the decisions of the European legislator and thus secured the Cartel Damages Directive in terms of primary European law.

34 The judgment does not contain an explicit statement on the discrepancy between a negative finding of a violation of art 102 TFEU in the proceedings of a national court and a preliminary reference procedure under art 267 TFEU: how could the Court asses the question under art 267 TFEU while the Directive was not applicable and Portuguese competition courts held that there was no violation of European law?

35 The answer lies in disregarding the Portuguese competition court's decision and in (informally) upholding the decision of the Portuguese competition authorities at least for the civil procedure on cartel damages. Indeed, under the Cartel Damages Directive, there is only a 'positive' effect binding civil courts to the decision of the competition authority but no 'negative' effect as to the national competition law procedures against the fines. The rationale is that civil proceedings shall not be suspended for those participants in a cartel who defend themselves against the fine. This has, however, a severe disadvantage

23 Art 102 para 1 TFEU reads in relevant part: ‘Any abuse by one or more undertakings of a dominant position within the internal market or in a substantial part of it shall be prohibited as incompatible with the internal market in so far as it may affect trade between Member States.' 
when civil courts proceed with awarding compensation, and a competition law court later finds that there was no violation to start with. Most European legal systems have (so far) no mechanisms to deal with these circumstances of such erroneous res iudicatae.

\section{CJEU 20 June 2019 - C-100/18, Línea Directa Aseguradora, SA v Segurcaixa, Sociedad Anónima de Seguros y Reaseguros, ECLI:EU:C:2019:517}

\section{a) Brief Summary of the Facts}

The electrical circuit of a car insured by Linea Directa caught fire while the vehi- 36 cle was parked for more than 24 hours in a private garage. The latter was covered by a home insurance policy issued by Segurcaixa. The latter sought to recover the amounts paid out to the property owner from the liability insurer of the car.

While the Spanish first instance court dismissed the action, the appellate $\mathbf{3 7}$ court reversed. The Tribunal Supremo now asks the CJEU for a preliminary ruling essentially on whether parking a car in a garage still constitutes a 'use of vehicles' within the meaning of art 3 para $1 \mathrm{MID},{ }^{24}$ thereby extending the scope of insurance cover also to vehicles that remain stationary for more than 24 hours. The referring court inter alia pointed to the fact that compulsory motor liability insurance would thereby be comparable to (and overlap with) a homeowner's insurance that covers liability arising from the mere possession or ownership of a vehicle.

\section{b) Judgment of the Court}

The Court answered the question in the affirmative and held that "parking a ve- 38 hicle in a private garage constitutes a use of that vehicle which is consistent with its function as a means of transport' (para 43).

It came to that conclusion by first pointing to the fact that defining the 'use 39 of vehicles' was not left to the discretion of the Member States, but can only be

24 Art 3 para 1 MID reads in relevant part: 'Each Member State shall ... take all appropriate measures to ensure that civil liability in respect of the use of vehicles normally based in its territory is covered by insurance. .... 
interpreted by the Court as an autonomous concept of EU law. It thereby has to observe the MID's aim not only to ensure the free movement of vehicles within the EU, but also 'to guarantee that the victims of accidents caused by those vehicles receive comparable treatment' (para 33). The Court further pointed to its most recent case law, which had already broadened the concept both of the vehicles covered as well as of their use. ${ }^{25}$

40 Turning to the actual question posed by the referring court, the CJEU 'held that the parking and the period of immobilisation of the vehicle are natural and necessary steps which form an integral part of the use of that vehicle as a means of transport' (para 41), irrespective of the duration of said period.

\section{c) Commentary}

41 This ruling is in line with a series of decisions in the recent past where the CJEU has continuously expanded the scope of the MID, thereby including accidents on private property ${ }^{26}$ or military grounds. ${ }^{27}$

42

While the outcome therefore was not entirely surprising, an important argument raised by the referring Tribunal Supremo was left unanswered - how can one now still distinguish insurance cover for potential liability arising from the 'use of a vehicle' (as regulated by the MID) on the one hand from property insurance policies on the other hand which also cover risks resulting from items (such as vehicles) stationary within a building, for example? The insurance industry is clearly left with some homework after this ruling.

Furthermore, it is somewhat odd to now explicitly extend the notion of 'use' to 'non-use', which shifts the focus simply to being the keeper of the vehicle. It is also hard to understand why a vehicle that is merely parked and not in use at all falls within the scope of the MID, while a vehicle parked with its engine running (though not for transportation) should not be covered, even if the ensuing harm is caused by the sheer weight of the vehicle. ${ }^{28}$

25 Eg CJEU 21.1.2016, C-359/14 and C-475/14, ERGO Insurance and Gjensidige Baltic, ECLI:EU: C:2016:40.

26 Eg CJEU 4.9.2014, C-162/13, Vnuk, ECLI:EU:C:2014:2146. On this case, see BA Koch/ T Thiede, European Union, in: E Karner/BC Steininger (eds), ETL 2014 (2015) 660, no 45 ff.

27 Cf CJEU 20.12.2017, C-334/16, Núñez Torreiro, ECLI:EU:C:2017:1007.

28 Cf CJEU 28.11.2017, C-514/16, Rodrigues de Andrade, ECLI:EU:C: 2017:908: Had the tractor of that case fallen over without its engine running, it would have been covered by the MID regime under the current interpretation of the Court - there is no alternative reading of this current ruling. The fact that the tractor's fall was caused by the vibrations of its running engine (!), 
It is quite strange to insist on guaranteeing the uniform protection of 'vic- 44 tims of accidents' if the fire of a stationary vehicle is already considered an 'accident', particularly since this will typically not happen in a cross-border case (unless the garage is directly on a country's border or is open to foreign visitors). Stretching the notion of the 'use of vehicles' as far as the CJEU already has (and will most likely continue to do in the future) highlights even further that the real lacunae of EU law are not in the field of insurance, but rather in liability law, towards where this interpretation is increasingly drifting. After all, art 3 para 1 MID only requires Member States 'to ensure that civil liability in respect of the use of vehicles ... is covered by insurance' (emphasis added), and not that anything resulting from the use of vehicles, however broadly defined, shall be covered. The interplay of 'civil liability' and 'insurance' has always been and continues to be ignored by the CJEU so far. The upcoming reform of the MID ${ }^{29}$ fails to address this, which leaves the matter on the to-do-list of the European legislator.

\section{CJEU 29 July 2019 - C-451/18, Tibor-Trans Fuvarozó és Kereskedelmi Kft v DAF TRUCKS NV, ECLI:EU:C:2019:635}

\section{a) Brief Summary of the Facts}

In 2016, the European Commission imposed fines of almost $€ 3$ billion for hard- 45 core cartel violations in the form of price fixing in the trucks cartel. In the case at hand, the claimant freighter, Tibor Trans, took legal action against a cartel member whose trucks it had purchased via the latter's Hungarian authorised dealers.

The Hungarian court of first instance held that it was not internationally $\mathbf{4 6}$ competent to rule on these claims and thus accepted the defendant cartelist's argument that the hard-core competition law violations had taken place in Germany. Moreover, the defendant could not have foreseen that the claim would be asserted in Hungary. The Hungarian appellate court had doubts and referred the question to the CJEU.

though the latter was not used for moving the tractor itself, but for the operation of a pump attached to it, was therefore in retrospect decisive to exclude this case from the MID's scope. Honni soit qui mal y pense.

29 See Koch/Thiede (fn 1) no $1 \mathrm{ff}$. 


\section{b) Judgment of the Court}

47 In its decision, the Court referred to the previous case law on art 7 para 2 of the Brussels Ia Regulation, ie the duplication of jurisdiction in tort at both the place of action and the place of damage ('ubiquity principle') (para 25). ${ }^{30}$

48 In the past, the CJEU's case law was quite vague with regard to indirect damage and the relevant place of said indirect damage, ${ }^{31}$ so that the Court clarified that the damage in the form of the cartelist's overcharge constituted direct damage to the plaintiff within the meaning of art 7 para 2 Brussels Ia Regulation, even though the trucks had not been acquired directly by the defendant cartelist (paras 30, 31).

49 Moreover, the Court held that this damage occurred on the cartelised market in Hungary, so that the courts there, as the courts at the place of damage, had international jurisdiction for the (whole) international damage.

\section{c) Commentary}

50 The defendant's argument, which was probably intended to confer exclusive jurisdiction to the courts of the place of action under art 7 para 2 Brussels Ia Regulation, would have considerably reduced the risks of litigation as, in the case of hard-core horizontal cartel agreements, the place of action is essentially meaningless.

51 In these cases, usually, there will not be a single, clearly identifiable place of the harmful conduct, that is, a (constant) place of agreement on noncompetitive behaviour. Such a place of agreement and thus a place of action only exists in the case of organisationally consolidated cartels, for instance, when the cartel members meet for the purpose of anti-competitive conduct at a trade fair or similar event.

52 It is highly debated how to proceed if the cartel is not a well-organised one or if cartelists use modern means of communication. In our view, one may simply acknowledge that in the case of horizontal cartel agreements the place of the causal event can hardly be precisely localised and proven and that the place of

30 See $T$ Thiede, EU Conflict of Laws, in: E Karner/K Oliphant/BC Steininger (eds), European Tort Law Basic Texts (2018) 414.

31 See Thiede (fn 30) 416 and BA Koch/T Thiede, European Union, in: E Karner/BC Steininger (eds), ETL 2015 (2016) 647, no $21 \mathrm{ff}$. 
the agreement, if it cannot be clearly determined, may ultimately be irrelevant for the question of jurisdiction.

Finally, one important passage of the Court's earlier CDC judgment ${ }^{32}$ seems $\mathbf{5 3}$ to have been lost: there the CJEU had held that, in principle, there is an exception to the mosaic principle in the case of follow-on actions for horizontal competition law infringements; in these cases the courts at the place of damage are 'responsible for deciding on the total damage which the allegedly injured company has suffered due to the additional costs for the purchase of the products affected by the cartel' and the national courts' competence is not limited to the damage that had occurred within the boundaries of their respective jurisdictions.

\section{CJEU 11 December 2019 - C-431/18, María Pilar Bueno Ruiz, Zurich Insurance PL, Sucursal de España v Irene Conte Sánchez, ECLI:EU:C:2019:1082}

\section{a) Brief Summary of the Facts}

On the way to her car on a parking lot, Ms Sánchez was injured when she $\mathbf{5 4}$ slipped on a puddle of oil that had leaked from Ms Bueno Ruiz' car that was parked nearby. Ms Sánchez now claims compensation for her loss from Ms Bueno Ruiz and the insurer of the latter's vehicle, claiming inter alia that she had been injured in a traffic accident within the meaning of the MID.

The Spanish first instance court agreed that the incident was covered by Ms $\mathbf{5 5}$ Bueno Ruiz' motor vehicle liability insurance. The appellate court, the Audiencia Provincial of Zaragoza, was not equally convinced and decided to refer this question to the CJEU. The referring court had taken note of the earlier ruling in Linea Directa Aseguradora, ${ }^{33}$ but was prepared to distinguish the current case inasmuch as here an alternative possible cause might have been the lack of proper maintenance (and cleaning) of the parking lot and not just a defect of the vehicle concerned.

32 CJEU 21.5.2015, C-352/13, CDC Hydrogen Peroxide, ECLI:EU:C:2015:335. On this case, see Koch/Thiede (fn 31) no $47 \mathrm{ff}$.

33 Above no $36 \mathrm{ff}$. 


\section{b) Judgment of the Court}

56 The Court repeated what it had already said half a year earlier in Linea Directa Aseguradora $^{34}$ and concluded here as well that a vehicle that leaks oil on a private parking space still falls within the notion of the 'use of vehicles' in art 3 para 1 MID. The fact that at least part of the oil was leaked in the process of starting and stopping the car was an even stronger argument as opposed to technical risks materialising only while the vehicle is stationary.

57 In response to the referring court's concerns, the Court noted that questions of causality or contributory negligence were matters of liability law not touched by the MID. Therefore, it is up to the Spanish court to determine how the confirmation of liability insurance cover by the CJEU works together with domestic tort law in Spain.

\section{c) Commentary}

58 Any other outcome of this case would have been surprising at least considering what the Court had said earlier that same year in the Linea Directa Aseguradora $^{35}$ case. However, the referring court's concern regarding the interplay of liability and insurance law were - again - ignored by the CJEU, underlining once more the importance of a final word by the EU legislator on this matter. ${ }^{36}$

\section{CJEU 12 December 2019 - C-435/18, Otis Gesellschaft m.b.H. and Others $v$ Land Oberösterreich and Others, ECLI:EU:C:2019:1069}

\section{a) Brief Summary of the Facts}

59 Between 1995 and 2004, several companies in the elevator and escalator industry fixed prices, divided markets, manipulated bids for procurement contracts and exchanged information. In 2007, the European Commission imposed a total fine of $€ 992$ million on the companies involved.

34 Above no $36 \mathrm{ff}$.

35 Above no $36 \mathrm{ff}$.

36 Above no 44. 
In February 2010, the Federal Province of Upper Austria filed a lawsuit $\mathbf{6 0}$ against a cartelist and claimed compensation for the interest loss incurred ('sunken costs'): the Province grants housing loans at lower or market rates. Due to the cartelised elevators, the amounts taken out as loans were higher. The difference between loans for housing projects with non-cartelised lifts and the loans actually granted could have been invested by the Province at the average interest rate of federal bonds.

The Austrian court of first instance dismissed the action as the Province was not deemed a protected market participant and had (at most) suffered indirect damage that could not be compensated. The appellate court, on the other hand, considered indirect damage to be covered by the scope of protection of art 101 TFEU and therefore annulled the decision of the court of first instance. Eventually, the Austrian Supreme Court asked the CJEU whether Austrian tort law must be interpreted to include damage suffered by parties that were not involved as suppliers or purchasers on the relevant product and geographic market affected by a cartel.

\section{b) Judgment of the Court}

As before, the Court refers to the direct applicability of art 101 TFEU (para 21). 62 Since it must be possible for 'any individual' to claim compensation for the damage that he/she has suffered as a result of a violation of competition law (para 22), a causal connection between the damage suffered and the conduct prohibited under art 101 TFEU is required only in principle (para 23). Since the broadest possible liability, even for remote damage, would deter undertakings from acting in violation of competition law, national rules such as the Austrian, which limit liability for indirect damage, are not applicable, because otherwise the effective implementation of art 101 TFEU would be jeopardised (para 25): not only damage resulting from direct market participation by the injured party but also indirect damage has to be compensated (para 27).

\section{c) Commentary}

From a comparative law perspective, the judgment is somewhat surprising. The 63 basic Austrian liability law norm of sec 1295 Austrian Civil Code (Allgemeines Bürgerliches Gesetzbuch, ABGB) corresponds - at least according to its wording - to the CJEU's 'every individual' case law. In contrast to that case law, however, the Austrian legal system over a period of more than 200 years (!) has de- 
termined that the choice of the word 'every individual' is clearly too broad, has carefully identified the restrictions presented above and, in particular, has recognised that the deterrent effect alone, on which the Court's decision is based, must be subject to certain limitations with regard to the preventive and compensatory functions of tort law and, moreover, the predictability of liability for the tortfeasor: the tortfeasor must therefore be able to recognise the relevant criteria in tort in order to act according to the rules' deterrent intention. With a view to the case at hand, this does not seem possible as the damage covered not only fails to include the cartelised market, not even an affiliated market (in this case: construction and work services), but instead concerns the market for financing construction projects in the form of a loss of interests by the public authorities. 